\title{
Effect of Silicon Addition on High-Temperature Solid Particle Erosion-Wear Behaviour of Mullite-SiC Composite Refractories Prepared by Nitriding Reactive
}

\author{
Xiaochao Li, ${ }^{1}$ Shusen Chen, ${ }^{1}$ Zhaohui Huang, ${ }^{1}$ Minghao Fang, \\ Yan'gai Liu, ${ }^{1}$ Xiaowen Wu, ${ }^{1}$ Juntong Huang, ${ }^{1}$ and Baolin Liu ${ }^{2}$ \\ ${ }^{1}$ School of Materials Science and Technology, National Laboratory of Mineral Materials, China University of Geosciences (Beijing), \\ Beijing 100083, China \\ ${ }^{2}$ Key Laboratory on Deep Geodrilling Technology of the Ministry of Land and Resources, China University of Geosciences (Beijing), \\ Beijing 100083, China
}

Correspondence should be addressed to Zhaohui Huang; huang118@cugb.edu.cn and Baolin Liu; lbaolin@cugb.edu.cn

Received 6 November 2013; Accepted 11 December 2013; Published 16 January 2014

Academic Editor: Majid R. Ayatollahi

Copyright (C) 2014 Xiaochao Li et al. This is an open access article distributed under the Creative Commons Attribution License, which permits unrestricted use, distribution, and reproduction in any medium, provided the original work is properly cited.

Solid particle erosion-wear experiments on as-prepared mullite-SiC composite refractories by nitriding reactive sintering were performed at elevated temperatures, using sharp black $\mathrm{SiC}$ abrasive particles at an impact speed of $50 \mathrm{~m} / \mathrm{s}$ and the impact angle of $90^{\circ}$ in the air atmosphere. The effects of silicon powder addition and erosion temperature on the erosion-wear resistance of mullite-SiC composite refractories were studied. The test results reveal that $\mathrm{Si}$ powders caused nitriding reaction to form $\beta$-sialon whiskers in the matrix of mullite-SiC composite refractories. The erosion-wear resistance of mullite-SiC composite refractories was improved with the increase of silicon powder addition and erosion temperature, and the minimum volume erosion rate was under the condition of $12 \%$ silicon added and a temperature of $1400^{\circ} \mathrm{C}$. The major erosion-wear mechanisms of mullite-SiC composite refractories were brittle erosion at the erosion temperature from room temperature to $1000^{\circ} \mathrm{C}$ and then plastic deformation from $1200^{\circ} \mathrm{C}$ to $1400^{\circ} \mathrm{C}$.

\section{Introduction}

With the development of technology of circulating fluidized bed boiler, garbage incineration boiler, and coke dry quench there is a growing demand for high-temperature erosionwear-resistant materials with better performances whereas the conventional wear-resistant materials cannot fully meet these requirements anymore. For instance, the refractory linings materials for circulating fluidized bed boiler are commonly eroded between $850^{\circ} \mathrm{C}$ and $1100^{\circ} \mathrm{C}$ by the coal powders, high-melting mineral impurity particles, and limestone grits for desulfurizing; their services can be severely shortened by such high-temperature erosion-wear $[1,2]$. At present, the commonly used wear-resistant refractories mainly include the traditional mullite-SiC [3], $\mathrm{SiC}$ bricks, and $\mathrm{Si}_{3} \mathrm{~N}_{4}$ /sialon bonded $\mathrm{SiC}$ [4]. The traditional mullite-SiC bricks cannot meet the serve in high temperature due to their low erosionwear resistance. $\mathrm{SiC}$ bricks and $\mathrm{Si}_{3} \mathrm{~N}_{4}$ /sialon bonded $\mathrm{SiC}$ bricks cannot be used on a large scale because of their high cost. Therefore, it is essential to devise a new sort of promising candidate erosion resistant material with high performance, low cost, and long service life.

$\beta$-sialon is a kind of solid solutions with the formula $\mathrm{Si}_{6-z} \mathrm{Al}_{z} \mathrm{O}_{z} \mathrm{~N}_{8-z}(0<z \leq 4.2)$ where $\mathrm{Si}^{4+}$ and $\mathrm{N}^{3-}$ are partially replaced by $\mathrm{Al}^{3+}$ and $\mathrm{O}^{2-}$, respectively. Such replacements without changing the crystal structure only increase the crystal unit sizes [5, 6]. Sialon-based materials are regarded as a promising candidate for erosion resistant materials, because of their excellent properties such as high strength, high toughness, chemical inertness, good wear resistance, corrosion resistance, and outstanding thermal shock resistance. For example, these sialon-based materials 
TABLE 1: Compositions of the samples.

\begin{tabular}{|c|c|c|c|c|c|c|c|c|}
\hline \multirow{2}{*}{ Sample } & \multicolumn{3}{|c|}{ Mullite with different grain size } & \multicolumn{2}{|c|}{ SiC with different grain size } & \multirow{2}{*}{$\mathrm{Si}$} & \multirow{2}{*}{$\mathrm{Al}_{2} \mathrm{O}_{3}$} & \multirow{2}{*}{ Binder } \\
\hline & $1 \sim 0.5 \mathrm{~mm}$ & $0.5 \sim 0 \mathrm{~mm}$ & $\leq 45 \mu \mathrm{m}$ & $0.2 \sim 0 \mathrm{~mm}$ & $\leq 45 \mu \mathrm{m}$ & & & \\
\hline M1 & 23 & 14 & 14 & 23 & 23 & 0 & 3 & 3 \\
\hline M2 & 23 & 14 & 10 & 23 & 23 & 4 & 3 & 3 \\
\hline M3 & 23 & 14 & 6 & 23 & 23 & 8 & 3 & 3 \\
\hline M4 & 23 & 14 & 2 & 23 & 23 & 12 & 3 & 3 \\
\hline
\end{tabular}

Content, wt.\%.

are widely used in valve seats, cutting tools, engines, cylinder liners, and other mechanical systems, which all requiring wear resistance at elevated temperatures [7-10]. Recently, the work on the wear properties of $\alpha / \beta$-sialon composites ceramics revealed that under mild wear conditions, the single phase $\alpha$-sialon materials showed better resistant under mild wear conditions. However, under more severe conditions, composites with higher $\beta$-sialon content showed better wear properties [11-13]. Chen et al. [14-17] have proposed that $\beta$ sialon could be easily prepared by high-temperature combustion syntheses, which were suitable for use as reinforcing agent in composites. It was found that with increasing $\beta$ sialon content in the composites, there was a monotonic increase in both bending strength and fracture toughness. Also, the wear resistance and fracture toughness of the material increased with increasing the size of elongated $\beta$ sialon grains. Therefore, introducing sialon phase into the mullite-SiC composite matrixes would be a useful approach for enhancing their erosion resistant.

Refractories consisting of aggregate and binder phases are regarded as representative brittle materials. The fracture toughness of material plays an important role in erosionwear resistance. We can predict the erosion-wear resistance to conduct the experiment on fracture toughness of materials. It is noted that a lot of research works have been done on the fracture toughness experiments for ceramics. In the present research work, fracture toughness was usually evaluated in three different stress states (which include pure mode I, pure mode II, and combined mode I and mode II) using the asymmetric in the four-point bending method by a centrally cracked Brazilian disk specimen for ceramics [18-33]. At present, we have not conducted the research on fracture toughness of materials in this paper, and we will emphasize and discuss the relationship between fracture toughness and the erosion-wear resistance in the next work.

In this paper, we employed silicon and $\mathrm{Al}_{2} \mathrm{O}_{3}$ powders as raw materials to in-situ nitride to generate sialon, which surrounded mullite and $\mathrm{SiC}$ particles to form sialon bonded mullite-SiC composite refractories. Mullite-SiC composite refractories with high performance and low cost were prepared by nitriding reaction sintered. The work on their preparation and mechanical properties, heated at different temperatures by carbonization reaction sintering, has been reported recently [3]. The as-prepared sialon bonded mullite$\mathrm{SiC}$ composite refractories could be developed as the linings materials of circulating fluidized bed boiler, garbage incineration boiler, and coke dry quench, which are usually suffered solid particles erosion. Up to now, the study on the erosionwear resistance of mullite-SiC composites refractories has not been reported previously. Therefore, in this paper, we investigated the solid particles erosion-wear behavior of the as-prepared mullite-SiC composite refractories by nitriding reactive sintering at high temperature. This work may provide theoretical basis for the development of wear-resistant refractory materials.

\section{Experimental Details}

The main starting materials used in the experiment were as follows: mullite $\left(\left(\mathrm{Al}_{2} \mathrm{O}_{3}+\mathrm{SiO}_{2}\right)\right.$ content $>98$ wt. $\%$, grain sizes $(0.5 \sim 0 \mathrm{~mm}, 1 \sim 0.5 \mathrm{~mm}, \leq 45 \mu \mathrm{m})$, Shanxi Xixiaoping Refractories, Ltd., China); $\alpha$-SiC (98 wt.\% pure, grain sizes $(0.2 \sim$ $0 \mathrm{~mm}, \leq 45 \mu \mathrm{m})$, Luoyang Refractory Research and Industry Trade Co., Ltd., China); silicon powder (98 wt.\% pure, grain size $\leq 45 \mu \mathrm{m}$, Luoyang Refractory Research and Industry Trade Co., Ltd., China); $\alpha-\mathrm{Al}_{2} \mathrm{O}_{3}$ powder (99.9 wt.\% pure, grain size $\leq 0.5 \mu \mathrm{m}$, Aluminum Corporation of China, Ltd.); nitrogen (purity $\geq 99.99 \mathrm{wt} . \%$ ); some sintering additives. Compositions of the samples are tabulated in Table 1, showing different addition amounts of silicon powder.

The starting materials according to the mixture ratio designed in Table 1 were mixed in the mixer and the right water into the mixture during the mixing process was added. After the mixing uniformity, the materials mixture was pressed at $40 \mathrm{MPa}$ for $30 \mathrm{~s}$ to get cylindrical samples of $\Phi$ $50 \mathrm{~mm} \times 10 \mathrm{~mm}$. Subsequently, the cylindrical samples were further compacted by cold isostatic pressing at $120 \mathrm{MPa}$ for $90 \mathrm{~s}$. Then these green bodies were dried at $110^{\circ} \mathrm{C}$ for $12 \mathrm{~h}$. Finally, the green bodies were sintered at the temperature of $1300^{\circ} \mathrm{C}$ and $1400^{\circ} \mathrm{C}$ for 90 minutes, then rose to $1500^{\circ} \mathrm{C}$ for $3 \mathrm{~h}$ in a nitrogen atmosphere. When the sintering process was finished, the fired samples were furnace-cooled to room temperature.

The erosion-wear experiments were performed by self-designed high-temperature solid particle erosion-wear equipment, according to ASTM G76-04. The schematic diagram of erosion-wear experiment is presented in $[2,34]$. Angular black SiC particles (the particles size of $325-830 \mu \mathrm{m}$ is more than 97\%) were used as abrasive particles. The pressure of compressed air was $0.45 \mathrm{MPa}$. The flux rate of impact particles was $60 \mathrm{~g} / \mathrm{min}$. The impingement angle of impact particles stream on the target was $90^{\circ}$ and impacted at different temperatures $\left(25^{\circ} \mathrm{C}, 200^{\circ} \mathrm{C}, 400^{\circ} \mathrm{C}, 600^{\circ} \mathrm{C}, 800^{\circ} \mathrm{C}\right.$, $1000^{\circ} \mathrm{C}, 1200^{\circ} \mathrm{C}$, and $1400^{\circ} \mathrm{C}$ ) with $100 \mathrm{~g}$ of black SiC particles. 


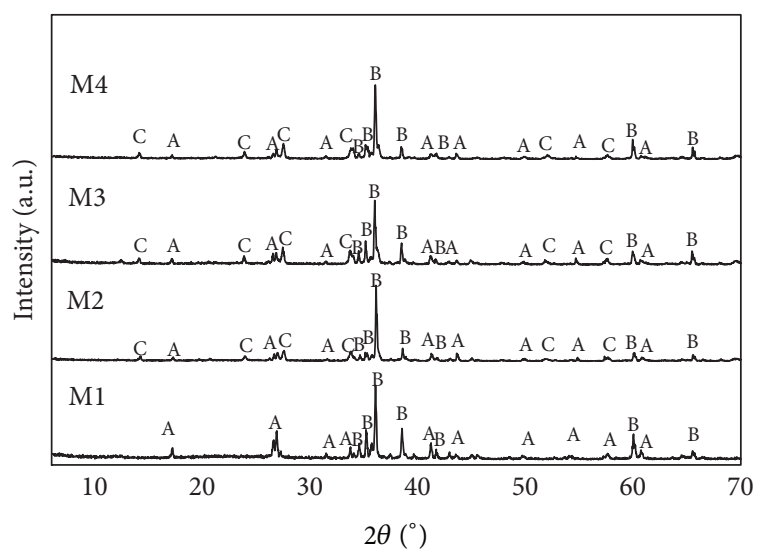

A: Mullite

B: $\alpha-\mathrm{SiC}$

C: $\mathrm{Si}_{3} \mathrm{Al}_{3} \mathrm{O}_{3} \mathrm{~N}_{5}$

FIGURE 1: XRD patterns of samples with different silicon powder addition nitridation sintered at $1500^{\circ} \mathrm{C}$ for $3 \mathrm{~h}$.

Solid particle erosion-wear resistance was characterized using volume erosion rate, which could be calculated with the following expression [2]:

volume erosion rate $\left(\mathrm{mm}^{3} / \mathrm{g}\right)$

$$
=\frac{\text { average mass loss }}{\text { specimen density } \times \text { the mass of impact particles }} \text {. }
$$

Archimedes water immersion method was used in the determination of bulk density and apparent porosity. According to the ASTM C1421-01b (R2007), the bending strength was determined via conventional three-point bending method with a support roller span of $20 \mathrm{~mm}$ and a crosshead speed of $0.05 \mathrm{~mm} / \mathrm{min}$ at room temperature, and the bend samples $(6 \mathrm{~mm} \times 6 \mathrm{~mm} \times 40 \mathrm{~mm})$ were tested more than three times. The crystalline phase was monitored via Xray diffraction (XRD, XD-3, $\mathrm{Cu} \mathrm{K} \mathrm{K}_{\alpha 1}$ radiation, $\lambda=1.5406$, Purkinje General Instrument Co., Ltd.). And the scanning electron microscopy (SEM, JEM-6460LV, Japan) was used to observe the microstructure of the samples eroded by $\mathrm{SiC}$ abrasive particles.

\section{Results and Discussion}

3.1. Effect of Silicon Addition on Phase, Microstructure, and Performance of Samples. Mullite-SiC composite refractories were prepared using $\beta$-SiC, mullite, $\mathrm{Si}$ and $\mathrm{Al}_{2} \mathrm{O}_{3}$ as raw materials by nitriding reaction sintering at $1500^{\circ} \mathrm{C}$ for $3 \mathrm{~h}$. Figure 1 shows the phase compositions of samples. As this figure shows, the phase compositions consist of mullite, $\alpha$ $\mathrm{SiC}$, and $\mathrm{Si}_{3} \mathrm{Al}_{3} \mathrm{O}_{3} \mathrm{~N}_{5}$, which were formed in samples only when silicon powder has been added. The appearance of $\mathrm{Si}_{3} \mathrm{Al}_{3} \mathrm{O}_{3} \mathrm{~N}_{5}$ was due to the nitriding reaction of silicon powder and $\mathrm{Al}_{2} \mathrm{O}_{3}$.

Figure 2 shows SEM photographs and EDS spectrum of samples. There are large amounts of whiskers structure to

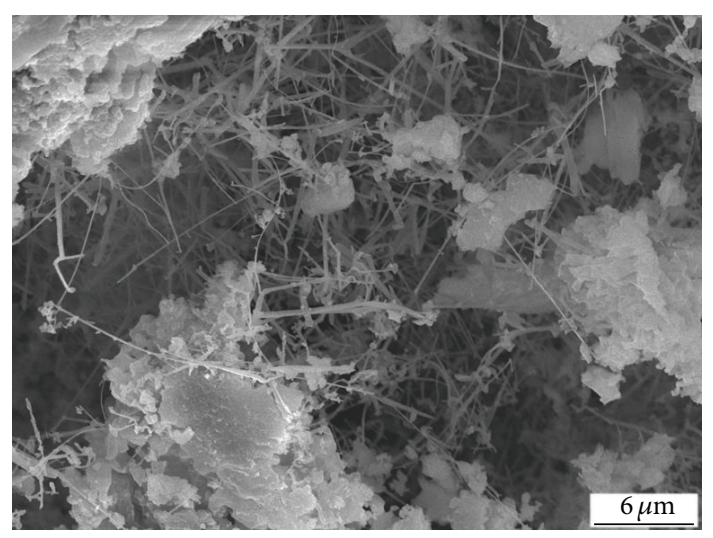

(a)

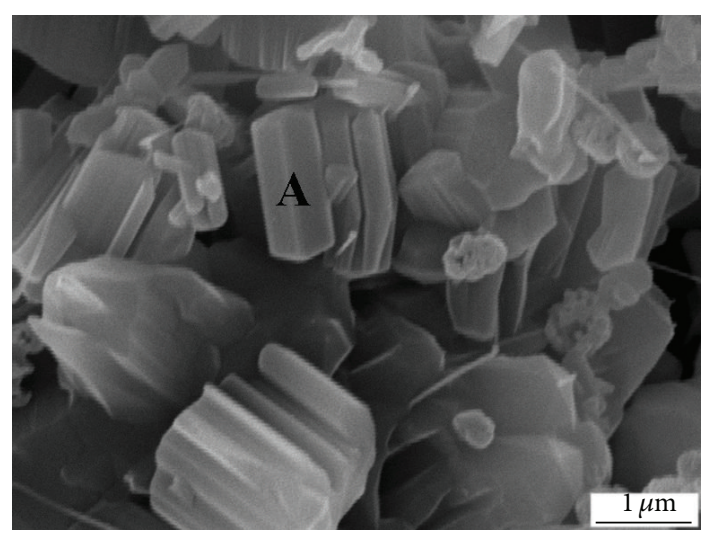

(b)

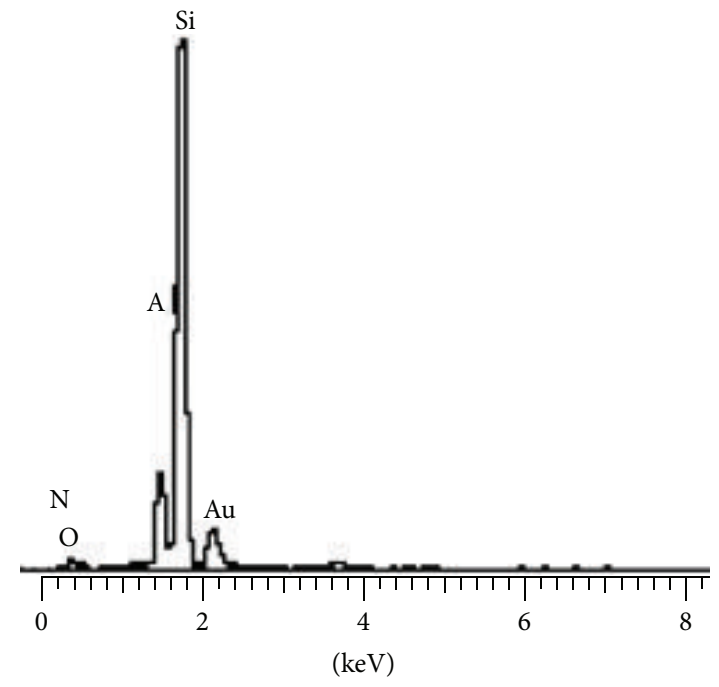

(c)

FIGURE 2: SEM photographs and EDS spectrum of samples: (a) surface fracture microstructure of sample M4; (b) surface microstructure of sample M4; (c) EDS spectrum of point A in (b).

form in the fracture surface of sample M4 (shown in Figure 2(a)). Moreover, the columnar-like structure is formed in the surface of sample M4 (shown in Figure 2(b)). It is believed that the columnar-like and whiskers consisted mainly of $\mathrm{Si}_{3} \mathrm{Al}_{3} \mathrm{O}_{3} \mathrm{~N}_{5}$ by XRD, SEM, and EDS analyses. The fundamental properties of samples are listed in Table 2. The properties of 
TABLE 2: Properties of mullite-SiC composite refractories prepared by nitriding reactive.

\begin{tabular}{lcccc}
\hline \multirow{2}{*}{ Property } & \multicolumn{4}{c}{ Samples } \\
& M1 & M2 & M3 & M4 \\
\hline Bulk density $\left(\mathrm{g} / \mathrm{cm}^{3}\right)$ & 2.12 & 2.15 & 2.19 & 2.27 \\
$\begin{array}{l}\text { Apparent porosity (\%) } \\
\begin{array}{l}\text { Cold compression } \\
\text { strength (MPa), } \geq\end{array}\end{array}$ & 28.4 & 27.2 & 26.1 & 23.6 \\
$\begin{array}{l}\text { Cold bending strength } \\
(\mathrm{MPa})\end{array}$ & 17.30 & 60 & 80 & 120 \\
$\begin{array}{l}\text { Vickers hardness of } \\
\text { binder phase }(\mathrm{GPa})\end{array}$ & 8.7 & 9.5 & 10.4 & 11.9 \\
\hline
\end{tabular}

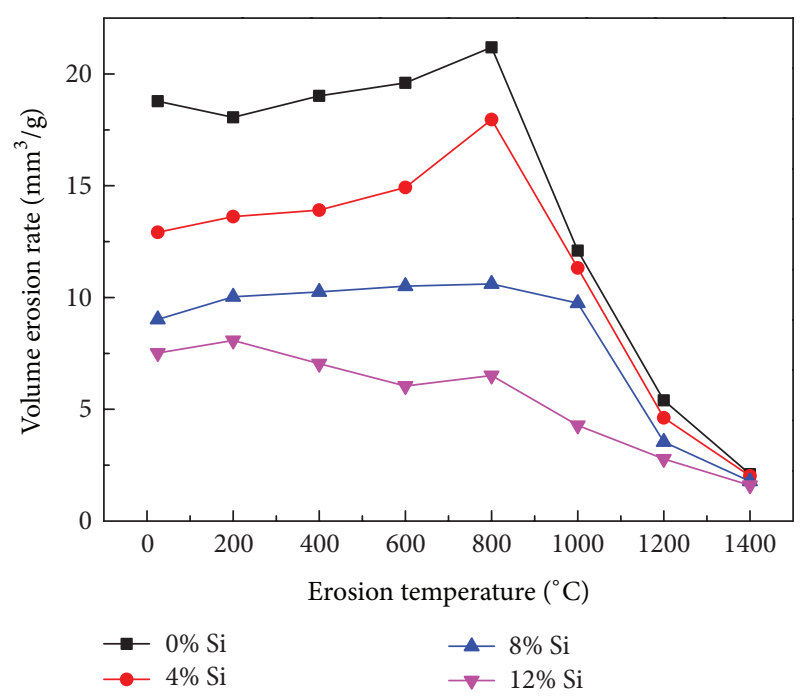

FIGURE 3: The volume erosion rates of the samples with respect to the test temperature and silicon powder addition.

sample M4 (12\% silicon powder added) are better than other samples.

\subsection{Effect of Silicon Addition and Erosion Temperature on the} Volume Erosion Rates of Samples. Figure 3 shows the effect of erosion temperature and silicon powder addition on the volume erosion rates of the samples. As Figure 3 reveals, the volume erosion rate tends to slightly change with increasing the erosion temperature from $25^{\circ} \mathrm{C}$ to $800^{\circ} \mathrm{C}$, then sharply decreases from $800^{\circ} \mathrm{C}$ to $1400^{\circ} \mathrm{C}$. The result reveals that mullite-SiC composites refractories had excellent high temperature erosion-wear resistance. The reasons can be explained as follows. The binder phase was softer and can show more plastic deformation at elevated temperatures. So it can consume and absorb more impact energy made by $\mathrm{SiC}$ erosion particles. Also at high temperature, the volume of aggregates would expand to a certain extent and make a higher bonding strength with the binder phase, which could improve the erosion-wear and spalling resistance of refractories.
As Figure 3 further reveals, the volume erosion rates of samples decreased sharply with the increasing of silicon powder addition at the erosion temperature from $25^{\circ} \mathrm{C}$ to $1000^{\circ} \mathrm{C}$ the reason could be due to the apparent porosity decrease and the mechanical properties improved with the increasing of silicon powder addition. Furthermore, the content of $\beta$ sialon increased with the increasing of silicon powder addition, which can improve the erosion-wear resistance at the experiment temperature from $25^{\circ} \mathrm{C}$ to $800^{\circ} \mathrm{C}$. The refractory linings materials of circulating fluidized bed boiler, garbage incineration boiler, and coke dry quench are commonly used at the temperature between $850^{\circ} \mathrm{C}$ and $1100^{\circ} \mathrm{C}$. The volume erosion rate of sample M4 (12\% silicon added) tends to slightly change and reach the lowest value about $5 \mathrm{~mm}^{3} / \mathrm{g}$ under the use of temperature between $850^{\circ} \mathrm{C}$ and $1100^{\circ} \mathrm{C}$. Therefore, sample M4 (12\% silicon added) can meet the use as the lining wear-resisting refractories.

3.3. Erosion-Wear Mechanisms Analysis. Refractories are regarded as brittle materials, which consist of coarse aggregate and binder phase. So the material removal of refractories is the main brittle erosion mechanism. Figure 4 shows erosion morphologies of the binder phase in the samples. As Figure 4 reveals, the structure of sample M1 (no silicon added) was loosened (shown in Figure 4(a)), and the bonding strength was weak in both aggregate and binder phases. Therefore, the aggregate was easier to be dropped due to impact of the $36 \mathrm{SiC}$ erosion particles, which caused the high volume of erosion rate. While the structure of sample M4 (12\% silicon added) was denser, the bonding strength of the aggregate and binder phases of sample M4 was improved. So the erosion mechanism of binder phase was mainly started from the defects on the edge of pores (shown in Figures 4(b) and $4(c))$ at low temperature in sample M4. Pores of the binder phase were enlarged gradually because of impact of the $36 \mathrm{SiC}$ erosion particles, which caused the loss of binder phase. The erosion damage for the sample M1 is more serious than the sample M4, which shows that the overall strength and erosion resistance of samples were improved with the increasing of silicon addition.

Figure 5 shows the typical brittle erosion mechanism of aggregate in sample M4 (12\% silicon added). As can be see from Figure 5, the cracks and brittle fractures have occurred in the aggregate during the impact of the $\mathrm{SiC}$ erosion particles. Then the material was removed as the brittle fracture of the aggregate, which causes the high erosion rates at low temperature. Given the above, we can know that the erosionwear resistance of samples was improved with the silicon addition. Also, the brittle erosion mechanism is a dominant model for the refractories removal at low temperature.

Figure 6 displays SEM images and EDS patterns of sample M4 (12\% Silicon added) eroded at $1400^{\circ} \mathrm{C}$. It can be seen from Figures 6(a) and 6(b) that $\alpha$-SiC on the surface of samples was oxidized at high temperature to form a thin dense $\mathrm{SiO}_{2}$ glassy film which can blunt the surface cracks and improve the high-temperature erosion resistant materials [35]. Figure 7 shows the representative plastic deformation mechanism of samples at high temperature. When erosion occurred at high temperature, the binder phase started to soften because of 


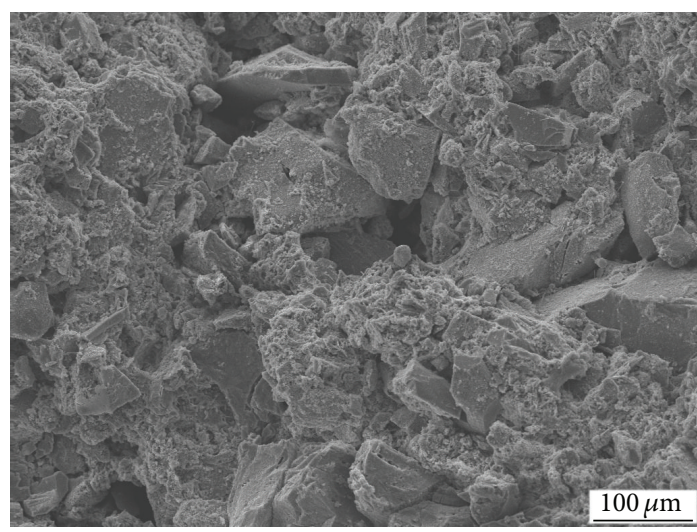

(a)

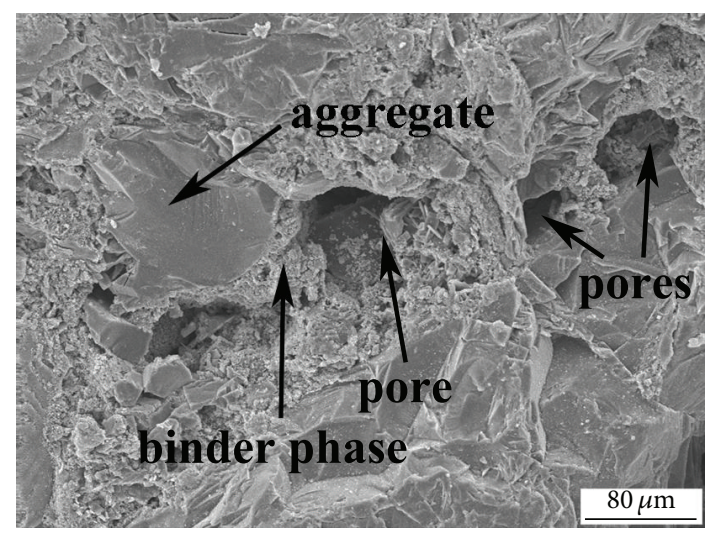

(b)

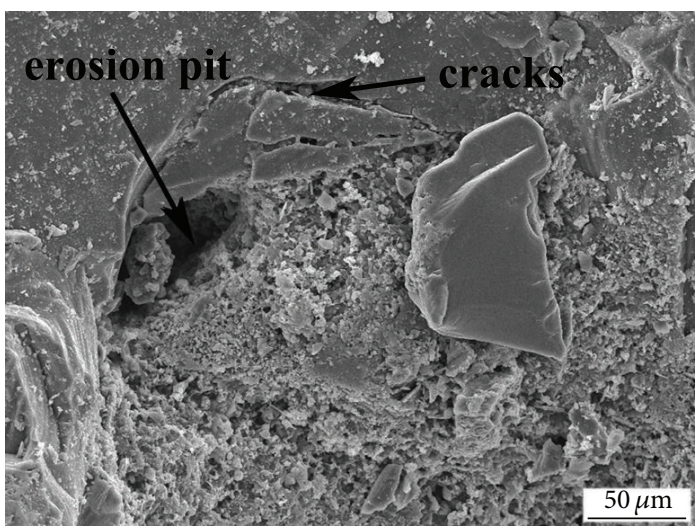

(c)

Figure 4: Erosion morphologies of the aggregate and binder phases in the samples: (a) sample M1 (no silicon added) eroded at $25^{\circ} \mathrm{C}$; (b) sample M4 (12\% silicon added) eroded at $25^{\circ} \mathrm{C}$; (c) sample M4 (12\% silicon added) eroded at $800^{\circ} \mathrm{C}$.

the oxidation and formed a layer of glass-like substance on the surface of samples, which can accommodate more plastic deformation. The plastic deformation can reduce sharply the volume erosion rate of material. However, there is still some brittle erosion at $1200^{\circ} \mathrm{C}$ in sample M1 (no silicon added), which caused the higher volume erosion rate than the sample M1.

We can conclude from the above study about phase, performance and microstructure of materials that the mechanical properties and erosion-wear resistance of samples increased with silicon powder addition. The results can be explained that the addition of silicon powder is helpful to form $\beta$-sialon whiskers (depicted in Figure 2), which can fill the void and enhance the toughness of the material. Some studies indicate that in situ formed whiskers in the material are without pollution and spread evenly, and the formation of whiskers can prevent grain slip and improve the toughness of material through the bridge and pull-out mechanism $[36,37]$. Furthermore, silicon powders had melted when sintered in $1500^{\circ} \mathrm{C}$ because of the low melting point $1410^{\circ} \mathrm{C}$ of silicon [3]. The liquid silicon may fill the space between particles and make particles combine more closely by the surface tension, which can decrease the porosity and increase volume density
[38]. Therefore, the mechanical properties and erosion-wear resistance of samples were improved with silicon powder addition.

\section{Conclusions}

The main phase of mullite-SiC composite refractories by nitriding reaction sintering is mullite, $\alpha$-SiC and $\beta$-Sialon, and in-situ form $\beta$-Sialon whiskers in the matrix of mullite$\mathrm{SiC}$ composite refractories can enhance the mechanical properties and erosion-wear resistance. The erosion resistance of mullite-SiC composite refractories increased with the increase of silicon powder addition and test temperature, and the minimum erosion rate was at $12 \%$ silicon added and $1400^{\circ} \mathrm{C}$. The major erosion mechanism of mullite-SiC composite refractories is brittle erosion at the temperature from room temperature to $1000^{\circ} \mathrm{C}$. The material removal is mainly due to the brittle fracture of aggregates and pores expansion of the binder phase causing the aggregates pullouts. From $1000^{\circ} \mathrm{C}$ to $1400^{\circ} \mathrm{C}$, the major erosion mechanism of mullite-SiC composite refractories is plastic deformation, which mainly resulted from oxidation and softening of the material. 


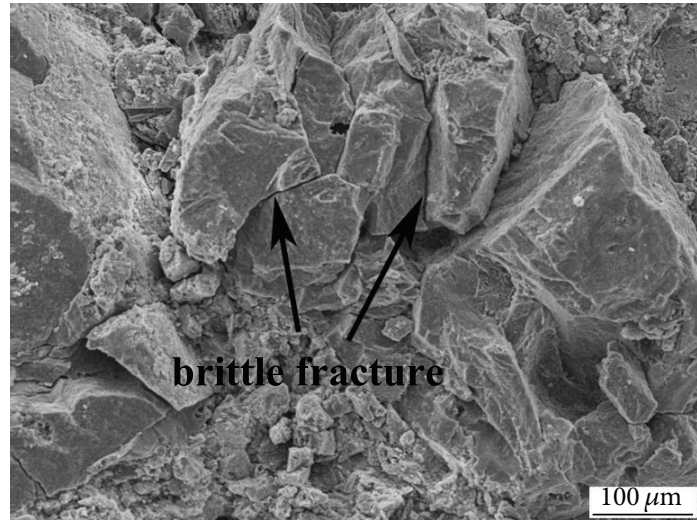

(a)

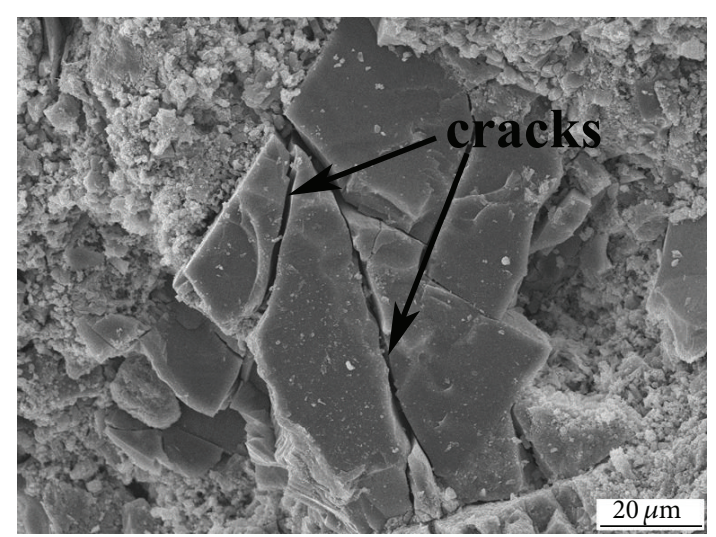

(b)

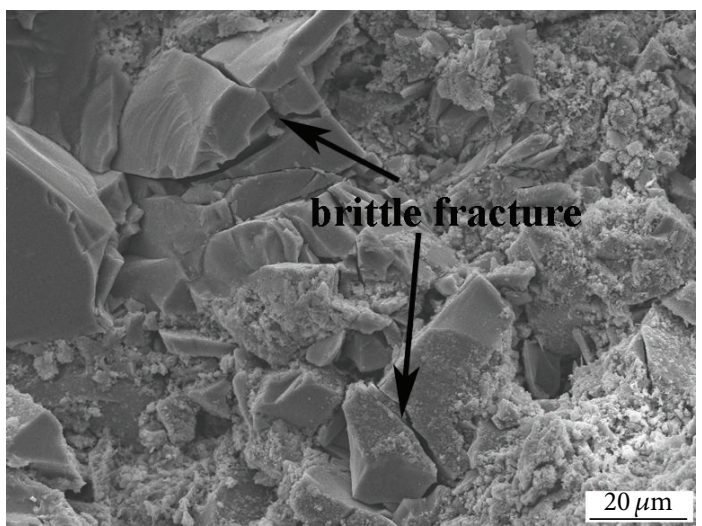

(c)

FIgURE 5: Typical brittle erosion morphologies of aggregate in sample M4 (12\% silicon added): (a) eroded at $25^{\circ} \mathrm{C}$; (b) eroded at $800^{\circ} \mathrm{C}$; (c) eroded at $1000^{\circ} \mathrm{C}$.

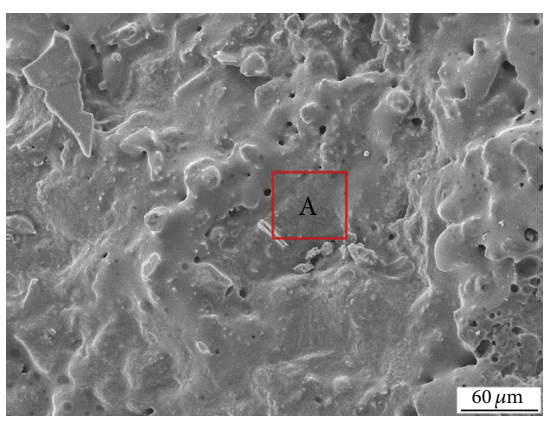

(a)

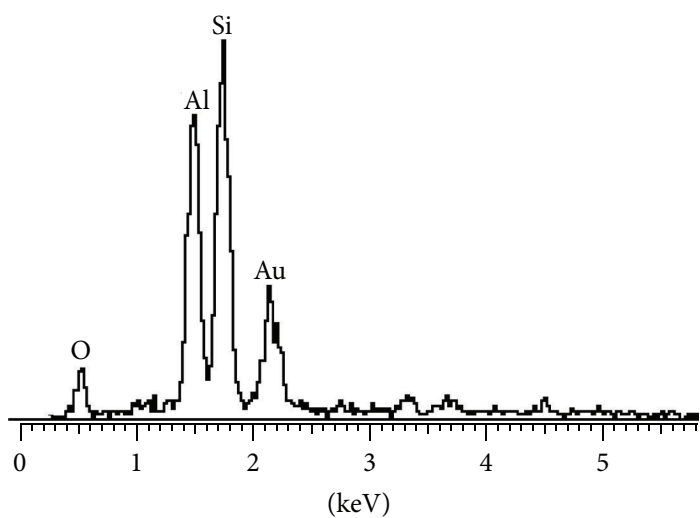

(b)

FIGURE 6: SEM images and EDS patterns of sample M4 (12\% silicon added) eroded at $1200^{\circ} \mathrm{C}$ : (a) SEM micrographs of the surface of sample and (b) EDS result of area A. 


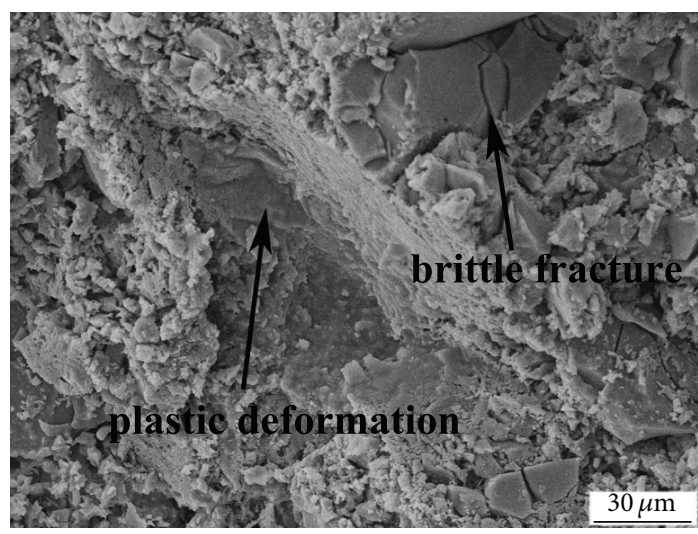

(a)

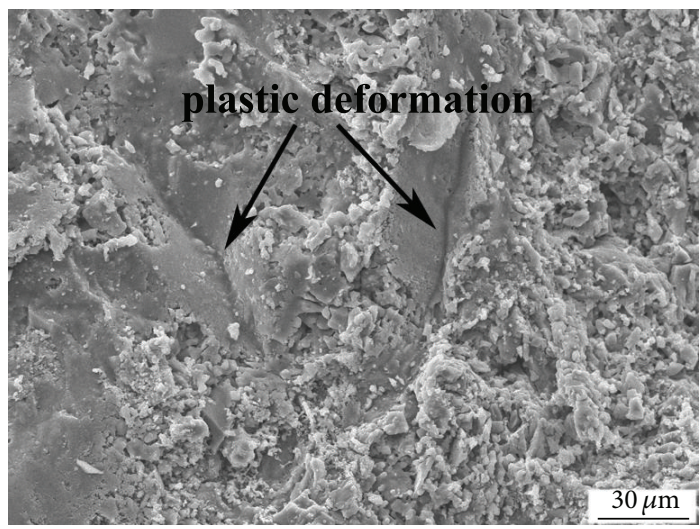

(b)

FIGURE 7: Representative SEM photography shows plastic deformation of samples: (a) sample M1 (no silicon added) eroded at $1200^{\circ} \mathrm{C}$ and (b) sample M4 (12\% silicon added) eroded at $1200^{\circ} \mathrm{C}$.

\section{Conflict of Interests}

The authors declare that there is no conflict of interests regarding the publication of this paper.

\section{Acknowledgments}

This work was financially supported by National Natural Science Foundation of China (Grant no. 51032007 and no. 51272241) and Research Fund for the Doctoral Program of Higher Education of China (Grant no. 20130022110006).

\section{References}

[1] J. P. Bennett and K. S. Kwong, "Refractory liner materials used in slagging gasifiers," Refractories Application and News, vol. 9, pp. 21-25, 2004.

[2] J.-Z. Yang, M.-H. Fang, Z.-H. Huang et al., "Solid particle impact erosion of alumina-based refractories at elevated temperatures," Journal of the European Ceramic Society, vol. 32, no. 2, pp. 283-289, 2012.

[3] X. C. Li, Z. H. Huang, Y. G. Liu et al., "Effect of silicon addition on mechanical properties of mullite-SiC composite refractories," Journal of the Ceramic Society of Japan, vol. 120, pp. 574578,2012
[4] D.-S. Park, B.-D. Han, D.-S. Lim, and I.-W. Yeo, "A study on wear and erosion of sialon- $\mathrm{Si}_{3} \mathrm{~N}_{4}$ whisker ceramic composites," Wear, vol. 203-204, pp. 284-290, 1997.

[5] J. T. Huang, Y. G. Liu, Z. H. Huang et al., "Ni( $\left.\mathrm{NO}_{3}\right)_{2}$-assisted catalytic synthesis and photoluminescence property of ultralong single crystal Sialon nanobelts," Crystal Growth \& Design, vol. 13, pp. 10-14, 2013.

[6] V. A. Izhevskiy, L. A. Genova, J. C. Bressiani, and F. Aldinger, "Progress in SiAlON ceramics," Journal of the European Ceramic Society, vol. 20, no. 13, pp. 2275-2295, 2000.

[7] T. Ekström and M. Nygren, "SiAlON ceramics," Journal of the American Ceramic Society, vol. 75, pp. 259-276, 1992.

[8] S. Kurama, M. Herrmann, and H. Mandal, "The effect of processing conditions, amount of additives and composition on the microstructures and mechanical properties of $\alpha$-SiAlON ceramics," Journal of the European Ceramic Society, vol. 22, no. 1, pp. 109-119, 2002.

[9] J. Huang, M. Fang, Y. Liu, and Z. Huang, "Preparation of $\beta$ Sialon from fly ash by carbothermal reduction-nitridation reaction," Key Engineering Materials, vol. 368, pp. 910-912, 2008.

[10] Z.-H. Huang, J.-Z. Yang, Y.-G. Liu et al., "Novel sialon-based ceramics toughened by ferro-molybdenum alloy," Journal of the American Ceramic Society, vol. 95, no. 3, pp. 859-861, 2012.

[11] J. M. Ferreira and K. X. Chen, "Toughening Y $\alpha$-sialon ceramics by using new-developed rod-like $\mathrm{Y} \alpha$-sialon crystals as reinforcing agents," Key Engineering Materials, vol. 224, pp. 269-274, 2002.

[12] M. I. Jones, K. Hirao, H. Hyuga, Y. Yamauchi, and S. Kanzaki, "Wear properties of $Y-\alpha / \beta$ composite sialon ceramics," Journal of the European Ceramic Society, vol. 23, no. 10, pp. 1743-1750, 2003.

[13] M. I. Jones, H. Hyuga, K. Hirao, and Y. Yamauchi, "Wear behaviour of single phase and composite sialon ceramics stabilized with $\mathrm{Y}_{2} \mathrm{O}_{3}$ and $\mathrm{Lu}_{2} \mathrm{O}_{3}$," Journal of the European Ceramic Society, vol. 24, no. 10-11, pp. 3271-3277, 2004.

[14] V. X. Lima Filho, J. P. Davim, C. A. Cairo, and J. M. F. Ferreira, "Preparation and characterization of SiAlON matrix composites reinforced with combustion synthesis rod-like SiAlON particles," International Journal of Refractory Metals and Hard Materials, vol. 27, no. 3, pp. 647-652, 2009.

[15] K. X. Chen, J. Haibo, H. Zhou, and J. M. Ferreira, "Microstructure and formation mechanism of combustion-synthesized rodlike Ca $\alpha$-sialon crystals," Journal of Materials Research, vol. 16, no. 7, pp. 1928-1934, 2001.

[16] K. Chen, M. E. F. L. Costa, H. Zhou, and J. M. F. Ferreira, "Novel rod-like yttrium $\alpha$-sialon crystalline powders prepared by combustion synthesis," Materials Chemistry and Physics, vol. 75, no. 1-3, pp. 252-255, 2002.

[17] R. Fu, K. Chen, X. Xu, and J. M. F. Ferreira, "Combustion synthesis of rod-like $\alpha$-SiAlON seed crystals," Materials Letters, vol. 58, no. 12-13, pp. 1956-1958, 2004.

[18] D. K. Shetty, A. R. Rosenfield, and W. H. Duckworth, "Mixed-mode fracture in biaxial stress state: application of the diametral-compression (Brazilian disk) test," Engineering Fracture Mechanics, vol. 26, no. 6, pp. 825-840, 1987.

[19] S. Dileep and D. K. Shetty, "Fracture toughness of polycrystalline ceramics in combined mode I and mode II loading," Journal of the American Ceramic Society, vol. 72, no. 1, pp. 78-84, 1989.

[20] D. Singh and D. K. Shetty, "Microstructural effects on fracture toughness of polycrystalline ceramics in combined mode I and 
mode II loading," Journal of Engineering for Gas Turbines and Power, vol. 111, pp. 174-180, 1989.

[21] D. Singh and D. K. Shetty, "Subcritical crack growth in sodalime glass in combined mode I and mode II loading," Journal of the American Ceramic Society, vol. 7, pp. 3597-3606, 1990.

[22] S. Y. Yarema, G. S. Ivanitskaya, A. L. Maistrenko, and A. I. Zboromirskii, "Crack development in a sintered carbide in combined deformation of types I and II," Strength of Materials, vol. 16, no. 8, pp. 1121-1128, 1984.

[23] S. Suresh, C. F. Shih, A. Morrone, and N. P. O’Dowd, "Mixedmode fracture toughness of ceramic materials," Journal of the American Ceramic Society, vol. 73, no. 5, pp. 1257-1267, 1990.

[24] H. Awaji and T. Kato, "Griffith criterion for mode II fracture of ceramics," in Proceedings of the 11th International Conference on Experimental Mechanics, pp. 1199-1204, Oxford, UK, 1998.

[25] M. R. Ayatollahi and M. R. M. Aliha, "Mixed mode fracture analysis of polycrystalline graphite-a modified MTS criterion," Carbon, vol. 46, no. 10, pp. 1302-1308, 2008.

[26] M. R. M. Aliha and M. R. Ayatollahi, "On mixed-mode I/II crack growth in dental resin materials," Scripta Materialia, vol. 59, no. 2, pp. 258-261, 2008.

[27] T. Machida and N. Isobe, "Evaluation of mixed-mode fracture toughness using cracked Brazilian disk," Transactions of the Japan Society of Mechanical Engineers A, vol. 61, no. 592, pp. 2552-2559, 1995.

[28] A. R. Rosenfield, "Fracture of brittle materials under a simulated wear stress system," Journal of the American Ceramic Society, vol. 72, no. 11, pp. 2117-2120, 1989.

[29] M. R. Ayatollahi and M. R. M. Aliha, "Mixed mode fracture in soda lime glass analyzed by using the generalized MTS criterion," International Journal of Solids and Structures, vol. 46, no. 2, pp. 311-321, 2009.

[30] M. R. Ayatollahi and M. R. M. Aliha, "Fracture analysis of some ceramics under mixed mode loading," Journal of the American Ceramic Society, vol. 94, no. 2, pp. 561-569, 2011.

[31] M. R. M. Aliha and M. R. Ayatollahi, "Analysis of fracture initiation angle in some cracked ceramics using the generalized maximum tangential stress criterion," International Journal of Solids and Structures, vol. 49, pp. 1877-1883, 2012.

[32] V. Tikare and S. R. Choi, "Combined mode I-mode II fracture of 12-mol\%-ceria-doped tetragonal zirconia polycrystalline ceramic," Journal of the American Ceramic Society, vol. 80, no. 6, pp. 1624-1626, 1997.

[33] M. Li and M. Sakai, "Mixed-mode fracture of ceramics in asymmetric four-point bending: effect of crack-face grain interlocking/bridging," Journal of the American Ceramic Society, vol. 79, no. 10, pp. 2718-2726, 1996.

[34] F. Liu, M. Fang, X. Wang, Y. Liu, and Z. Huang, "Solid particle erosion behavior of 3YSZ ceramics at elevated temperatures," Key Engineering Materials, vol. 492, pp. 85-88, 2012.

[35] Z. H. Huang, J. L. Sun, J. X. Wang, and Y. R. Hong, “ $\beta$-sialon$\mathrm{Al}_{2} \mathrm{O}_{3}$-SiC composite refractories," Key Engineering Materials, vol. 224, pp. 275-280, 2002.

[36] J. B. Wachtman, W. R. Cannon, and M. J. Matthewson, Mechanical Properties of Ceramics, John Wiley \& Sons, New York, NY, USA, 2009.

[37] E. Karamian and A. Monshi, "Influence of additives on nano$\mathrm{SiC}$ whisker formation in alumina silicate-SiC-C monolithic refractories," Ceramics International, vol. 36, no. 2, pp. 811-816, 2010.
[38] M. W. Barsoum and B. Houng, "Transient plastic phase processing of titanium-boron-carbon composites," Journal of the American Ceramic Society, vol. 76, pp. 1445-1451, 1993. 

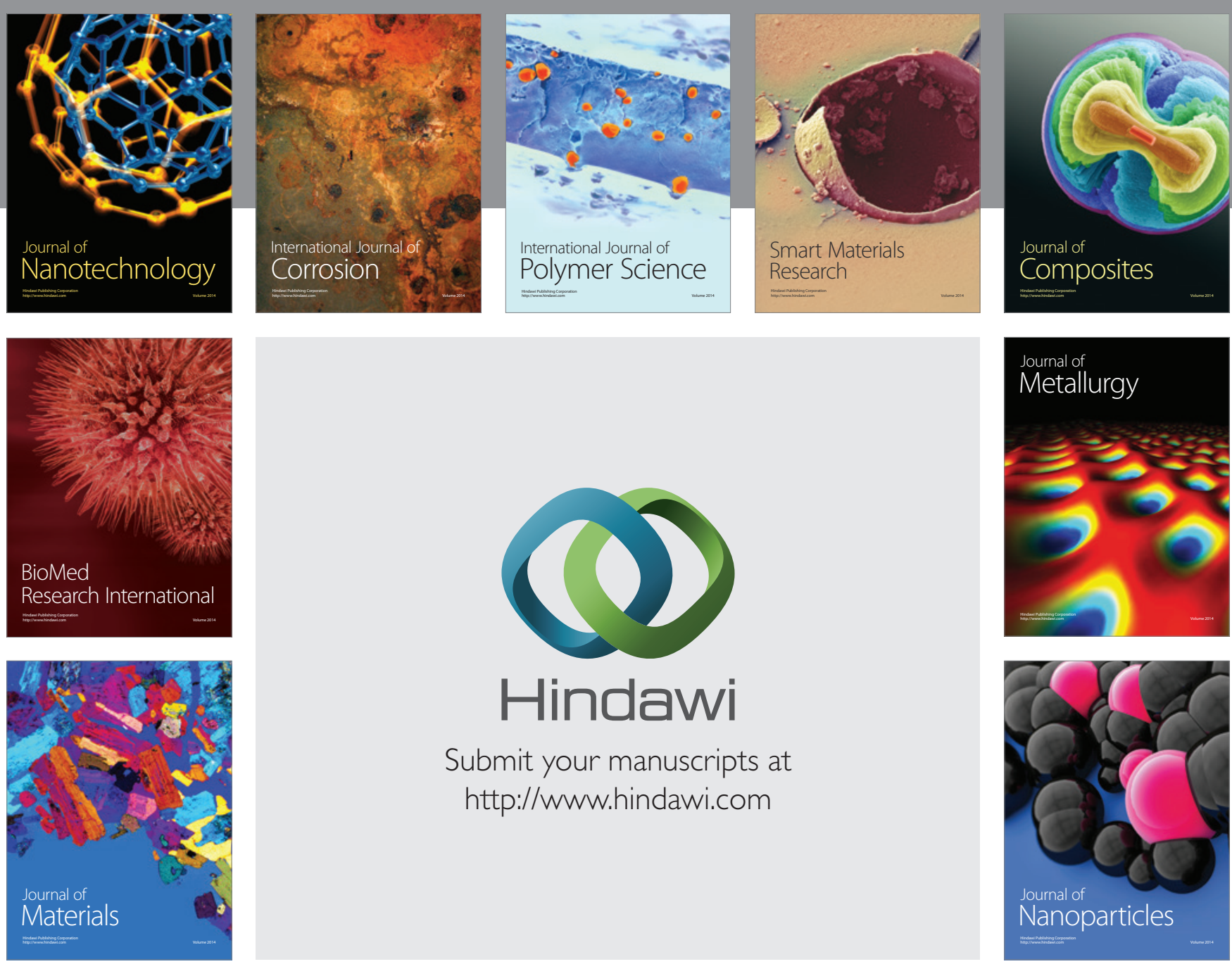

Submit your manuscripts at http://www.hindawi.com
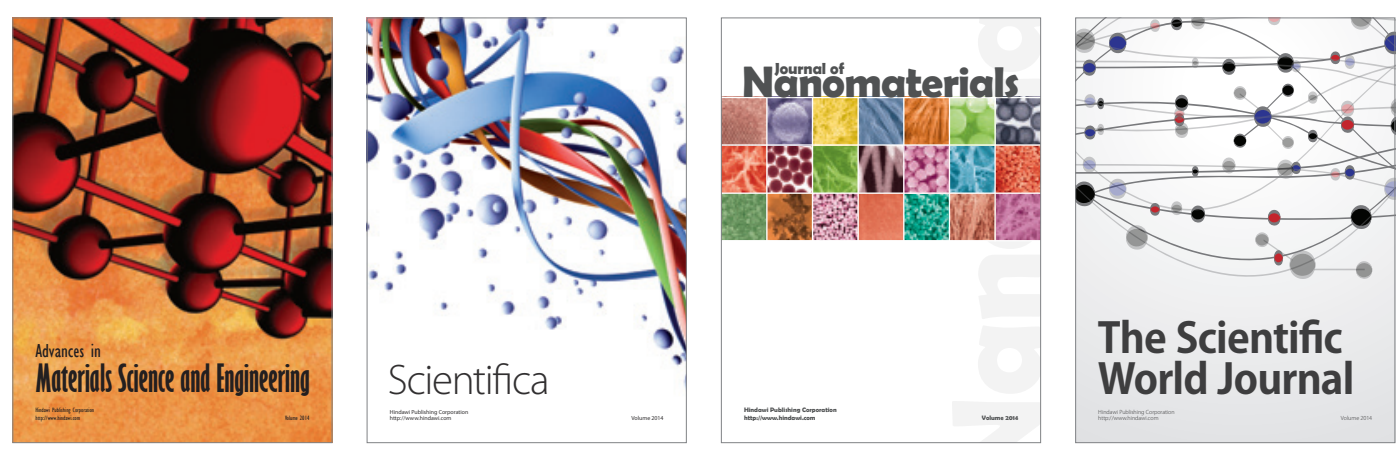

\section{The Scientific World Journal}
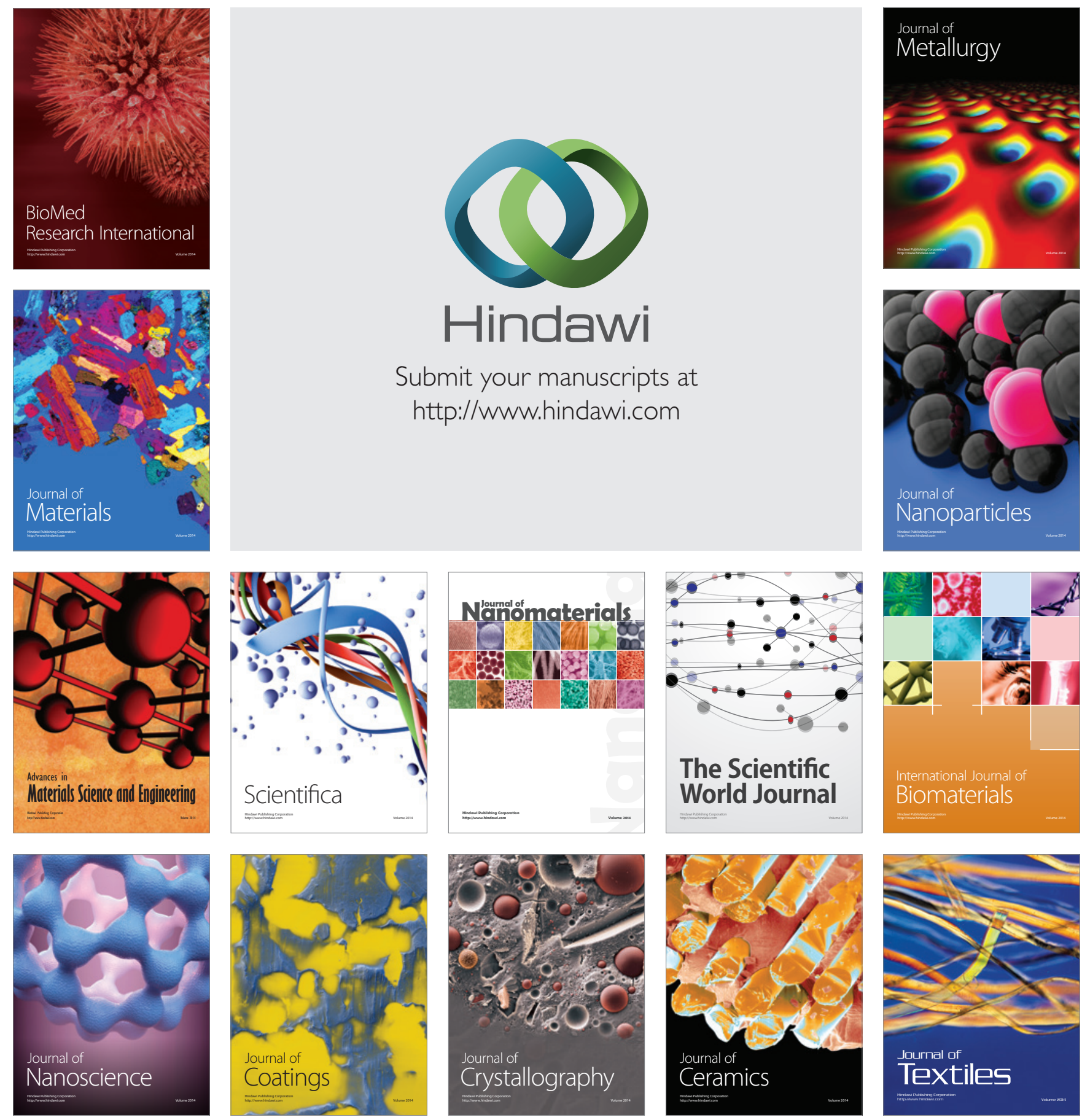